\title{
Amacrine Cell Interactions Underlying the Response to Change in the Tiger Salamander Retina
}

\author{
Greg Maguire, Peter Lukasiewicz, and Frank Werblin \\ Neurobiology Group, University of California, Berkeley, California 94720
}

The neural circuitry and pharmacology underlying transient signal formation at the bipolar-amacrine cell interface were studied. Synaptic currents were measured with whole cell patch clamp in retinal slices. Cell types were identified with Lucifer yellow staining. Activity was initiated with puffs of kainate of known time course and spatial spread delivered at bipolar dendrites. OfF bipolar cells responded to kainate with a sustained inward current, but on bipolar cells were silent.

Two types of amacrine cell were found: (1) narrow field cells, with processes that extended laterally less than 200 $\mu \mathrm{m}$, responding with a sustained inward current, and (2) wide field cells, with processes that extended laterally by up to $1 \mathrm{~mm}$, responding with a brief transient inward current followed by a more sustained outward current.

We pharmacologically dissected the synaptic interactions underlying the transient current in the wide field amacrine cell. In the presence of 5-aminovaleric acid (AVA), the time course of this transient current was increased so that it resembled the response of bipolar cells. Because AVA is a $\mathrm{GABA}_{\mathrm{B}}$ antagonist, it appears to block an opposing signal that truncates the sustained excitatory bipolar input, thereby generating the transient. $\mathrm{GABA}_{\mathrm{B}}$ specificity is confirmed by (1) block of the transient inward current by baclofen, a GABA agonist, and (2) block of the baclofen effect by AVA.

The site of $\mathrm{GABA}_{B}$ action appears to be presynaptic to the amacrine cell membrane because neither baclofen nor AVA, in combination with picrotoxin, had a direct effect at the amacrine cell membrane. $\mathrm{GABA}_{\mathrm{B}}$ receptors are often found at presynaptic terminals where they modulate calcium or potassium conductances. It has been shown that bipolar cell terminals receive a GABAergic synaptic input (Vaughn et al., 1981; Wu et al., 1981; Tachibana and Kaneko, 1987). The narrow field sustained-responding amacrine cells appear to be GABAergic (Werblin et al., 1988). This suggests that transient activity measured in wide field amacrine cells is formed at a population of bipolar cell terminals by GABAergic feedback from narrow field amacrine cells at $\mathrm{GABA}_{B}$ receptors.

\footnotetext{
Received Nov. 4, 1987; revised Apr. 28, 1988; accepted July 8, 1988.

This work was supported by NIH Grant EY00561 (to F.W.), Postdoctoral Fellowships EY05986 (to G.M.), and EY05751 (to P.L.). We thank Scott Eliasof for computer assistance, Dr. Steven Barnes for help with initial experiments, and Ciba-Geigy for its gift of baclofen. Thanks also to Dr. John McReynolds for his helpful comments on the manuscript.

Correspondence should be addressed to Frank Werblin, Neurobiology Group, University of California, Berkeley, CA 94720.

Copyright (C) 1989 Society for Neuroscience $0270-6474 / 89 / 020726-10 \$ 02.00 / 0$
}

Distal retinal cells respond with relatively sustained activity to maintained illumination, yet many retinal ganglion cells respond transiently, to only the arrival and/or departure of light (Barlow and Levick, 1965; Werblin and Dowling, 1969; Kaneko, 1970; Werblin, 1970, 1972; Nelson et al., 1978). A class of amacrine cells responds with similar transient properties and appears to transiently inhibit all ganglion cell types (Werblin and Copenhagen, 1974; Wunk and Werblin, 1978; Belgum et al., 1983, 1984) and neighboring amacrine cells (Barnes and Werblin, 1987). Synaptic inputs to amacrine (Werblin, 1977) and oN-OFF ganglion cells (Wunk and Werblin, 1978; Lukasiewicz and Werblin, 1986) are more transient than bipolar responses (Werblin and Dowling, 1969; Kaneko, 1970, 1973; Werblin, 1979), suggesting that one of the important transitions to more transient activity is initiated at sites distal to the amacrine cells but proximal to bipolar cell bodies. The questions of where transient action is initiated, what pathways are involved, which synaptic transmitters are utilized, and what mechanism of interaction mediates this transient action remain unresolved.

Two mechanisms for neuronal interaction have been proposed to account for transient activity in amacrine cells: (1) the algebraic summation of inputs from ON and OFF bipolar cells (Toyoda et al., 1973; Miller, 1979), and (2) transient transmitter release from bipolar cells (Marchiafava and Torre, 1978; Toyoda and Fujimoto, 1984).

Pharmacological studies have defined some of the important inhibitory synaptic inputs to cells at the inner plexiform layer (IPL). One component of transient lateral inhibitory transmission from amacrine to other amacrine and ganglion cells appears to be mediated by glycine (Frumkes et al., 1981; Belgum et al., 1984; Mittman and Copenhagen, 1985; Barnes and Werblin, 1987). There is also an inhibitory GABAergic input to ganglion cells (Miller et al., 1981; Belgum et al., 1984). Histochemical evidence (Vaughn et al., 1981; Wu et al., 1981) suggests a GABAergic input to bipolar cell terminals. A class of sustained amacrine cells shows evidence of GABA uptake (Marc et al., 1978). No link has been shown between glycinergic or GABAergic activity and the formation of transient activity.

We have attempted to determine the functional role and site of action for the cells and synapses that mediate transient activity. Two types of amacrine cell were morphologically identified by Lucifer yellow staining during patch recording in retinal slices. In slices we could test directly the sustained, transient, inhibitory, or excitatory action of a transmitter substance on a specific cell type. Our results lead to a scheme of synaptic interaction involving classes of sustained and transient bipolar and amacrine cells synaptically coupled in a change-sensitive retinal subunit. The subunit generates a signal that is signifi- 


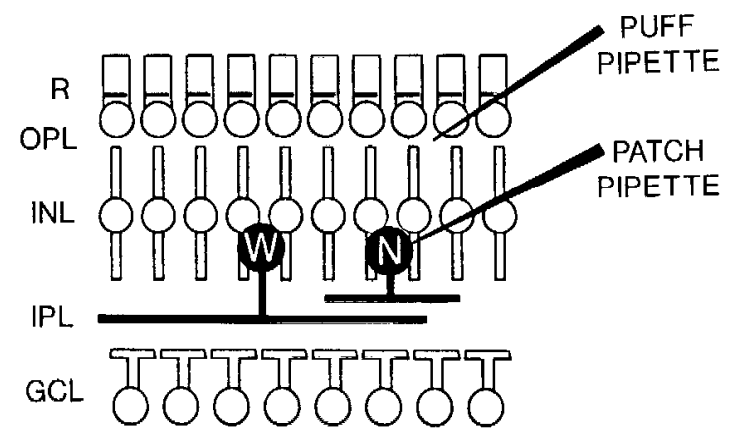

Figure 1. Geometry for stimulating and recording in the retinal slice. The puff pipette, containing $10 \mu \mathrm{m}$ kainate, was positioned within 10 $\mu \mathrm{m}$ of the dendrites of bipolar cells at the outer plexiform layer. Patch recordings were made with Lucifer yellow-filled electrodes. Morphologically identified bipolar cells and wide $(W)$ and narrow $(N)$ field amacrine cell types were easily identified. $R$, receptor layer; $O P L$, outer plexiform layer; $I N L$, inner nuclear layer; $I P L$, inner plexiform layer; $G C L$, ganglion cell layer.

cantly more transient than that in bipolars and may provide the appropriate signal for previously described systems of change detection (Barlow and Levick, 1965).

\section{Materials and Methods}

Whole cell patch recording in retinal slices. Details regarding the application of whole cell patch recording (Hamill et al., 1981) to amacrine cells in retinal slices (Werblin, 1978) have been described in detail elsewhere (Barnes and Werblin, 1986, 1987).

Calibration of the puff. Responses were elicited by "puffing" kainate $(10 \mu \mathrm{M})$ through the tip of a $1 \mu \mathrm{m}$ diameter pipette (Fig. 1). The pipette tip was placed within $10 \mu \mathrm{m}$ of the bipolar dendrites and kainate was released by pressure of 10 PSI for $40 \mathrm{msec}$ using a solenoid-controlled pneumatic valve. Kainate has been shown to mimic the actions of glutamate on second order neurons (Shiells et al., 1981; Slaughter and Miller, 1985). Bipolars in turn appear to release glutamate or an analog onto third-order neurons (Slaughter and Miller, 1983a, b).

The spatial and temporal properties of release by the puff were approximated in two different ways.

1. We measured the decrease in light transmission generated by a puff of an opaque dye at a $10-\mu \mathrm{m}$-wide slit projected by the microscope condenser (Fig. $2 F$ ). A $40 \times$ objective was focused on the puff pipette ejecting the dye (Fig. 2D). The change in transmission was measured by a silicon photodiode placed at the ocular. The puff pipette contained a saturated solution of Procion Black (C180) dissolved in Ringer's, then filtered. The photocell response as measured at different displacements for the pipette is shown in Figure $2 A$.

2. Occasionally while puffing at the outer plexiform layer (OPL) and recording from a bipolar cell, a very narrow region of sensitivity or "hot spot" was found. This probably represented an isolated region of dendritic processes, and provided a narrow spatial region of sensitivity that was useful as a bioassay for the spread of the puff. The response of the bipolar cell to puffs at different displacements of the pipette is shown in Figure $2 B$.

The spatial distribution of the puff as derived by each method is plotted in Figure $2 C$. The puff had an effective range of about $50 \mu \mathrm{m}$. The rise time of the responses was less than $100 \mathrm{msec}$ when the puff was closer to the center of the slit or to the sensitive region of the bipolar process and increased to nearly $1 \mathrm{sec}$ at displacements of about $35 \mu \mathrm{m}$, probably because of diffusion time.

The time course and spatial distribution of both bipolar and photocell responses are quite similar. This is probably due to the similarity in relation between puff and measurement area (Fig. $2 E$, shaded regions): the bipolar cell dendrites measure the integrated change in concentration of transmitter in a small slab along the surface of the slice; the photocell measures the integrated change in absorption (concentration) across a small slab formed by the narrow shaft of light created by the slit. The measured change in dye density is a reasonable approximation to the change in kainate concentrations that are significant for the bipolar cell response. Both photocell and bipolar responses were sustained when
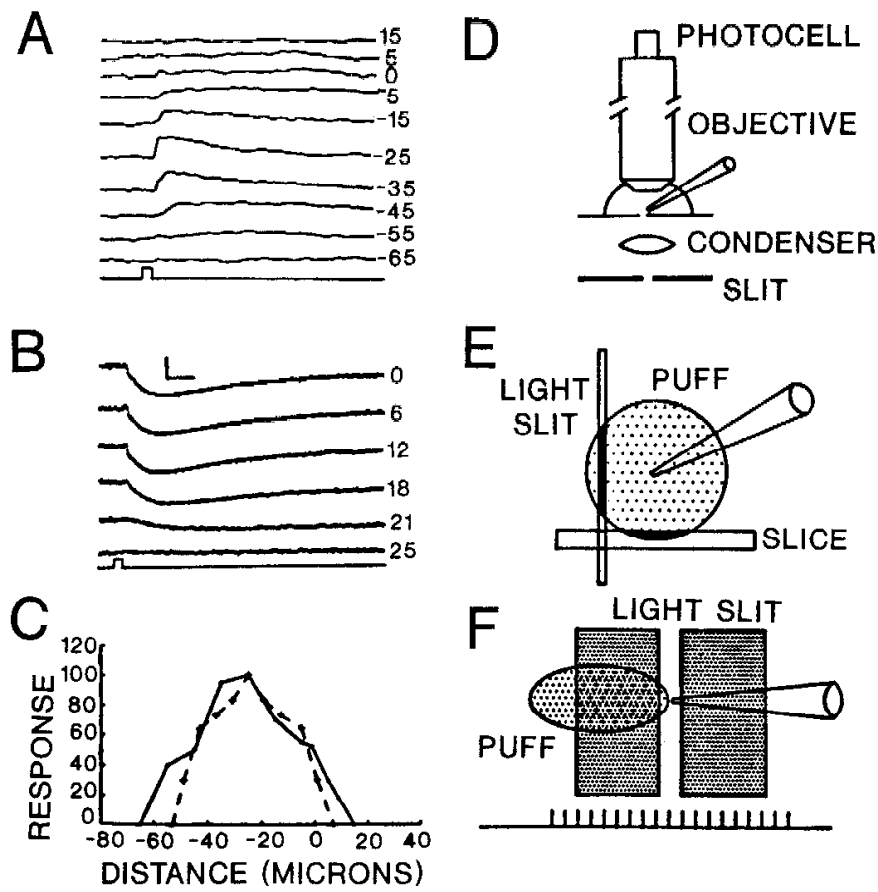

Figure 2. Calibration of the puff. $A$, Responses of photocell to puffs of Procion black viewed through a $10-\mu \mathrm{m}$-wide slit (see Materials and Methods). Distances from pipette tip to center of the slit are shown to the right of the traces. Responses negative to $0 \mu \mathrm{m}$ are minimal because the puff was completely obscured by the edge of the slit. Smaller responses are slower because of increased diffusion times. Calibration: 10 pA; 100 msec. $B$, Responses of bipolar cell "hot spot." A very narrow receptive region consisting of a single bipolar dendritic process was used as bioassay for the extent of the puff. Zero was taken at the position of largest response, and numbers to the right of the traces measure displacement from that point. Responses become smaller and slower as distance increases. $C$, Plot spatial spread of photocell response (solid curve) and (dashed curve). The hot spot curve is reflected around the maximum response and positioned along the abscissa so that the peak coincides with the photocell curve. Both curves suggest that the effective spread of the puff is less than $100 \mu \mathrm{m} . D$, Geometry of the pipette, slit, and puff. The slit $(10 \mu \mathrm{m})$ was placed between the light source and condenser and focused at the pipette with the condenser. The pipette was then focused at the photocell. E. Comparison of geometries for the puff stimulation of the slice and light slit. The time course and spatial distribution of the bipolar and photocell responses are similar. This is probably due to the similarity in the relationship between puff and measurement areas for the slice and slit, as shown in the shaded regions. $F$, Top view of the geometry of the light slit, puff pipette, and puff of Procion black dye. Measurements in $A$ reflect responses to the puff of dye when the pipette tip is at different perpendicular distances from the center of the slit; " 0 " represents the center of the slit.

the puff duration was extended, but longer puffs caused erratic puff quantities and pipette clogging during prolonged use. Therefore, we used only short duration puffs for consistent stimuli. We refer to responses that follow the trajectory of the puff as "sustained" and those that are clearly much briefer as "transient."

Because retinal tissue is a partial diffusion barrier, kainate probably penetrates the slice by considerably less than $50 \mu \mathrm{m}$. Therefore, only a fraction of the total dendritic field, namely, that located near the surface of the slice, is affected by the puff.

Standard electrode and bathing solutions. Our standard intracellular solution consisted of (in mM): potassium gluconate, 106; potassium chloride, 10; HEPES, 4; EGTA, 1; and calcium chloride, 0.1 buffered to $\mathrm{pH} 7.4$

The bathing medium contained (in mM): sodium chloride, 120; potassium chloride, 2; calcium chloride, 4; magnesium chloride, 1; HEPES, 4 buffered to plI 7.8 .

Picrotoxin $(50 \mu \mathrm{M}), 5$-aminovaleric acid (AVA; $0.5 \mathrm{mM}$ ) or baclofen $(50 \mu \mathrm{M})$ were added to the bathing medium (without substitution) to 
Figure 3. Photomicrographs of Lucifer yellow-filled amacrine cells. $A$, Wide field amacrine cell with processes distributed broadly across the IPL. $B$, Narrow field amacrine cell with processes distributed locally within sublamina $b$ of the IPL. Calibration bar, $25 \mu \mathrm{m}$.
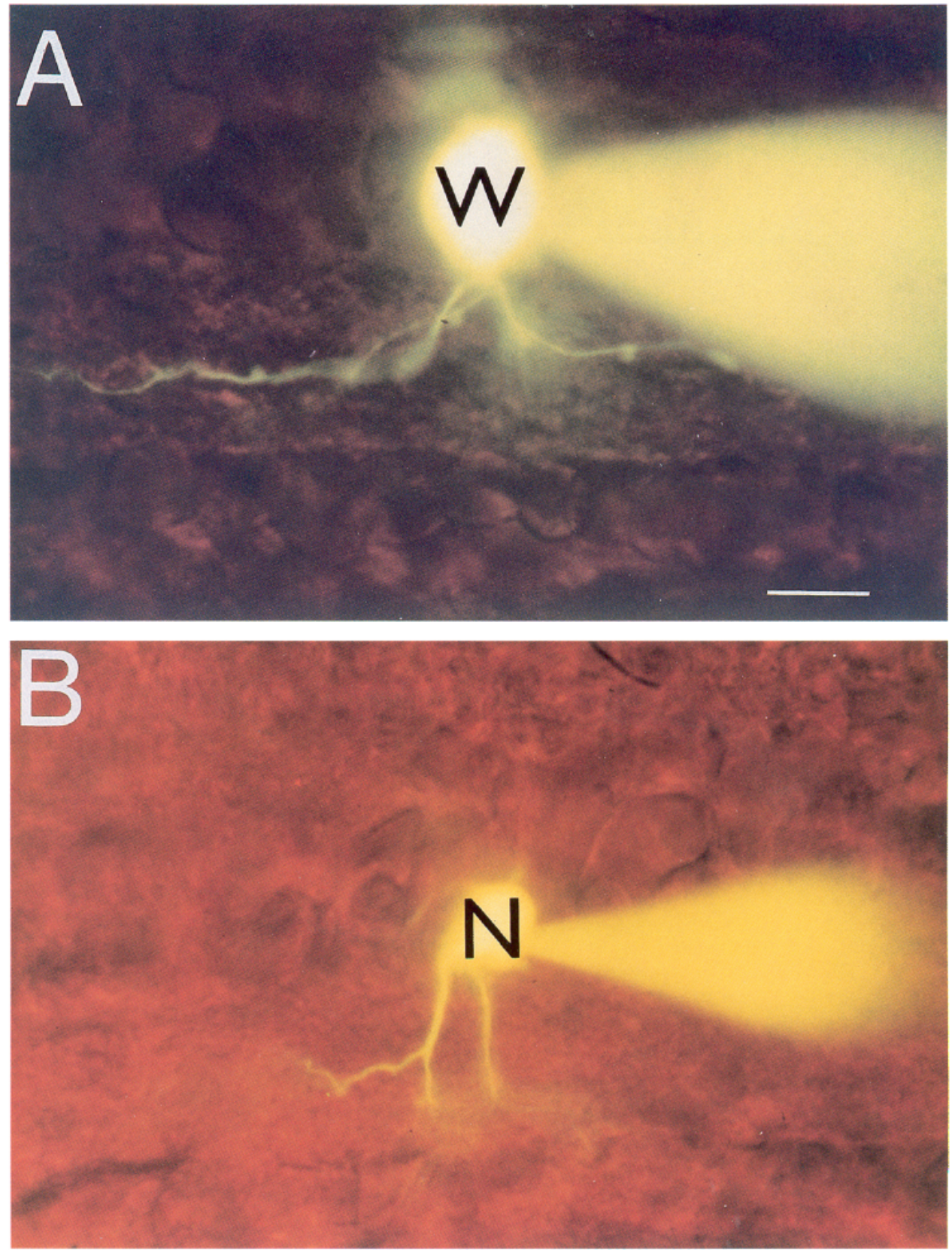

block or drive $\mathrm{GABA}_{\mathrm{A}}$ and $\mathrm{GABA}_{\mathrm{B}}$ receptors. Because AVA is a $\mathrm{GABA}_{\mathrm{A}}$ agonist as well as a $\mathrm{GABA}_{\mathrm{B}}$ antagonist (Muhyaddin et al., 1982), it was always used with picrotoxin for specific $\mathrm{GABA}_{\mathrm{B}}$ antagonism.

Cells were stained with Lucifer yellow by filling the patch electrodes with a $1 \%$ solution (Stewart, 1978). The stain diffused into the cell and its processes within $3 \mathrm{~min}$, so identification could be made during recording. Cells and processes were viewed using a Nikon mercury fluorescent epi-illuminator with the B filter package.

Liquid junction potential correction. Liquid junction potentials were determined by first placing the electrodes in a bath containing the electrode solution to establish a zero offset potential. Then we measured the offset from the zero potential in normal bathing media. The offset was $3 \mathrm{mV}$ when the electrode contained $120 \mathrm{mM} \mathrm{Cl}^{-}$and $116 \mathrm{mM} \mathrm{Cs}^{+}$, $4 \mathrm{mV}$ at $120 \mathrm{mM} \mathrm{Cl}^{-}$and $116 \mathrm{mM} \mathrm{K}^{+}$, and $11 \mathrm{mV}$ at $20 \mathrm{mM} \mathrm{Cl}^{-}$and $116 \mathrm{~mm} \mathrm{~K}^{+}$. Membrane potential values in this paper are corrected for these junction potentials.

Data acquisition and analysis. Recordings were obtained with a List EPC-7 electrometer. Electrode series resistance was reduced to 5-10 $\mathrm{M} \Omega$. This was verified by measuring the membrane charging curve under current clamp to obtain the time constant and membrane resistance.
From these values the membrane capacitance could be calculated. Then the series resistance was derived from the charging curve obtained under patch clamp since membrane capacitance was known. Typical values were: input resistance, $2 \mathrm{G} \Omega$; cell capacitance, $5 \mathrm{pF}$; series resistance, 7 M $\Omega$. All recordings of synaptic currents were made with the membrane held at a fixed potential. For the values given, little error in potential or kinetics was introduced by the series resistance.

The data were digitized and stored with an IBM PC/XT using a Data Translation 2800 analog interface board. Analysis was performed using software developed in this laboratory.

Adequacy of the voltage clamp. Because the voltage clamp is performed on neurons in the slice where their highly branched processes remain intact, it is important to verify that synaptic inputs occurring on the branches are adequately space clamped (Brown and Johnston, 1983). By using focal puffs of transmitter all synaptic inputs to the amacrine cell are confined to a region close to the soma.

The space clamp of the synaptic inputs was verified by comparing reversal potentials for the endogenous GABAergic input (picrotoxinsensitive component) and that of GABA puffed directly onto the soma or proximal processes that were between -60 and $-65 \mathrm{mV}$, the cal- 


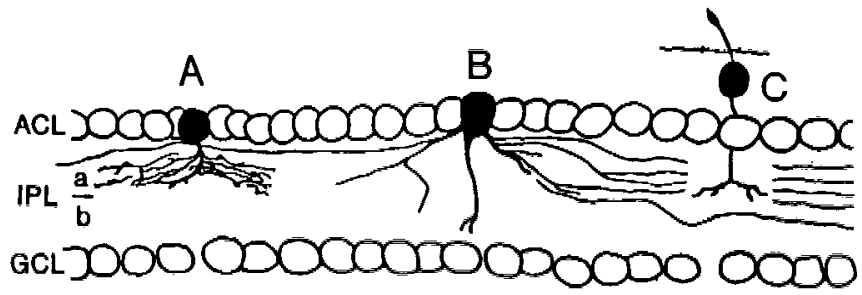

$\overline{25 \mu \mathrm{M}}$

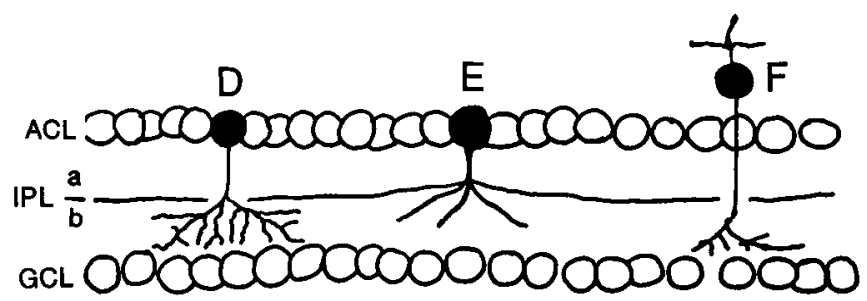

Figure 4. Morphology of most frequently encountered cells. Lucifer yellow staining used. The full extent of processes is shown by sketching a composite from separate photomicrographs for each cell taken at 3 different focal planes through the slice. Cells are arranged here for convenience of presentation. $A$, Narrow field amacrine cell with diffuse processes extending laterally by about $150 \mu \mathrm{m}$ and limited to sublamina $a$. Twenty-two cells were stained. $B$, Wide field diffuse amacrine cell with processes extending laterally by 500 to $1000 \mu \mathrm{m}$. A region near the soma extending only about $75 \mu \mathrm{m}$ contained tufted and thick processes, differing from the thinner, sparser processes seen more laterally. Twenty-cight cclls wcre staincd. $C$, Bipolar cell with axon tcrminating deep in sublamina $a$ and extending laterally by less than $50 \mu \mathrm{m}$. Twelve cells were stained. $D$, Narrow field amacrine cell with processes in sublamina $b$ extending laterally by about $100 \mu \mathrm{m}$. Twenty cells were stained. $E$, Wide field confined amacrine cell. Thin lateral processes extending up to $1000 \mu \mathrm{m}$ are limited to a region near the $a-b$ border. A second set of thicker lateral processes extends about $100 \mu \mathrm{m}$. Twenty-three cells were stained. $F$, Bipolar cell with axon terminal in sublamina $b$. Lateral extent of axons is limited to less than $100 \mu \mathrm{m}$. Eight cells were stained.

culated Nernst potential of $-62 \mathrm{mV}$, suggesting that the sites of GABAergic synaptic input are well clamped.

For these studies it was not necessary to determine the precise reversal potential or kinetics of responses. So our measurements would have been adequate even if the sites of synaptic input were not perfectly clamped.

\section{Results}

Amacrine cell morphology: Wide and narrow field amacrine cells

Two morphologically distinct types of amacrine cell were identified based on the lateral distribution of their processes and the sublaminae in which they ramify. Photomicrographs typical of the two main cell types are shown in Figure 3, and a more complete catalog and description of their morphology is given in Figure 4. Narrow field cells as shown in Figure $4, A, D$, were characterized by a dendritic arbor that extended laterally less than $200 \mu \mathrm{m}$, sending a diffuse projection confined to either the inner (Fig. $4 D$ ) or outer (Fig. $4 A$ ) half of the IPL. Cells ramifying in sublamina $b$ correspond to the small field amacrine cells of Vallerga (1981).

Wide field cells as shown in Figure $4, B, E$, had processes extending laterally by at least $500 \mu \mathrm{m}$ and typically extended to $1 \mathrm{~mm}$. These showed different forms of dendritic stratification either multistratified in the distal and proximal regions of the IPL as in Figure $4 B$ or confined to the central strata of the IPL

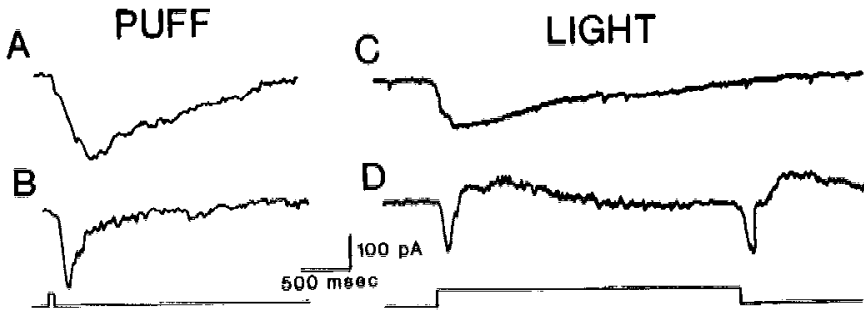

Figure 5. Comparison of puff and light responses. A, Puff response of narrow field cell (OFF type), $B$, Puff response of broad field cell (ON=OFF type). $C$, Light response of narrow field cell (on type). $D$, Light response of broad field cell (ON-OFF type). The narrow field response to either puff or light is significantly broad, with rise time of about $200 \mathrm{msec}$ and decay lasting beyond $500 \mathrm{msec}$. Narrow field response resembles that of the bipolar cell in Figure 2. The wide field cell response to either puff or light is brief, with a rise time of less than $50 \mathrm{msec}$ and a decay time of less than 150 msec. Thus, the response forms can be easily distinguished by either light or puff. Puff pipettes contained $10 \mu \mathrm{M}$ kainate. Light was full field and white. Light responses were studied in 8 sustained and 11 transient cells. In these, resting potentials were between -65 and $-70 \mathrm{mV}$ for sustained and between -70 and $-75 \mathrm{mV}$ for transient cells.

as in Figure $4 E$. The wide field cells correspond to the class II cells of Wong-Riley (1974) and the wide field cells of Vallerga (1981).

All cells studied lacked processes extending into the inncr nuclear layer or axons extending into the ganglion cell layer. They all showed voltage-gated transient inward currents and could be made to spike with depolarization under current clamp. These criteria confirm the identification as amacrine cells and help to exclude bipolar, interplexiform, or displaced ganglion cells from our measurements.

Each amacrine cell type had characteristically different response kinetics to puffs of kainate or glutamate presented at the dendrites of bipolar cells, as described below.

Responses to either light or puffs are sustained in narrow field amacrine cells and transient in wide field amacrine cells

We correlated both puff- and light-elicited synaptic currents in the 2 morphological types of amacrine cells. The currents in Figure $5, A, B$, were elicited by puffs, those in Figure $5, C, D$, by light, from narrow and broad field cells, respectively. Traces in Figure 5, $A, C$, in narrow field cells, have time courses similar to that of the photocell in Figure 2 (puff-like), whereas those in Figure $5, B, D$, elicited in wide field cells, have responses that are considerably more transient.

Puffs of kainate or glutamate applied directly at the processes of either amacrine cell type consistently elicited inward currents with puff-like kinetics as shown in Figure 1. This suggests that the more transient response is not a property of the glutamatelike sensitivity of the amacrine cells but is established presynaptically. We refer to the responses that follow the photocell kinetics as "sustained" or "slow" and those that are clearly briefer as "transient" or "fast." We qualify the use of the term "sustained" for our narrow field cells because they do show relaxation of the synaptic current over a period of seconds of continued light stimulation (see Fig. 5C). This may reflect the shaping of the synaptic inputs in bipolar cells by voltage-gated currents (Tessier-Lavigne et al., 1988).

These results show that either puffs or light can be used to distinguish between sustained or transient activity in amacrine cells. The response forms, correlated with the 2 types of ama- 

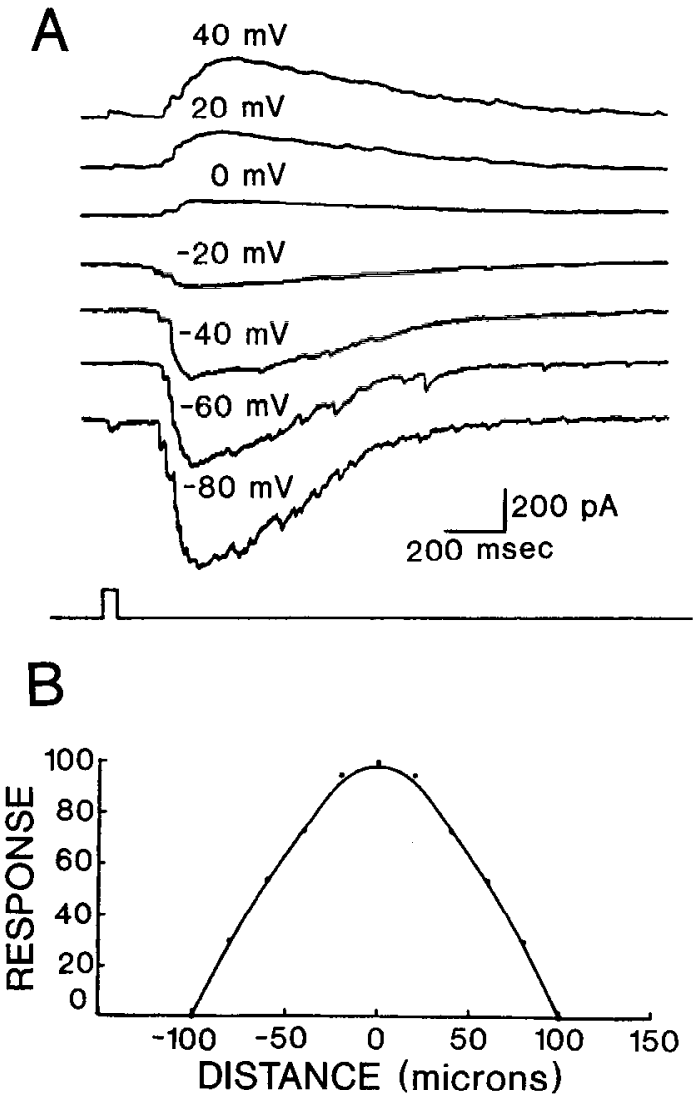

Figure 6. Narrow field amacrine cell currents. $A$, Reversal potential near $0 \mathrm{mV}$ for the inward synaptic current. Holding potential is shown above each trace. More than 39 cells were studied, with resting potentials between -65 and $-70 \mathrm{mV}$. $B$, Response profile for excitatory input to narrow field cell. Puffs were presented at the OPL and displaced laterally in $20-\mu \mathrm{m}$ intervals. Largest response was taken at position zero. The curve was measured on one side only and then rotated for completeness. The excitatory region for the narrow field amacrine cell spanned about $200 \mu \mathrm{m}$. The extent of processes for this cell type is about $150 \mu \mathrm{m}$ (Fig. $4 A)$.

crine cells, correspond roughly to a similar dichotomy described by Vallerga (1981) in light-elicited responses in the eyecup. In the following we used puffs because their spatial profiles were more readily controlled.

Bipolar and amacrine cells with processes confined to the inner half of the IPL (sublamina $b$ ) did not respond to puffs of kainate or glutamate at the OPL (Famiglietti and Kolb, 1976; Famiglietti et al., 1977; Stell et al., 1977; Kolb, 1979; Attwell et al., 1987). Our result is opposite from that of Slaughter and Miller (1985) who found that on bipolars responded better than OFF bipolars to kainate. The silence of the oN amacrine cells suggests that there is little crosstalk between the on and ofF pathways at the amacrine cell level, which is consistent with Miller and Dacheux (1976). We used puffs of kainate only as a tool for eliciting synaptic inputs to the third-order neurons in the OFF pathway; the lack of kainate and glutamate sensitivity in the on pathway is currently being investigated but is beyond the scope of this paper.

In the presence of $2 \mathrm{mM} \mathrm{Co}^{2+}$ in the bath, no response was recorded in amacrine cells to OPL kainate puffs. This controls for the possibility that kainate diffused from the OPL to the IPL to directly excite amacrine cells.
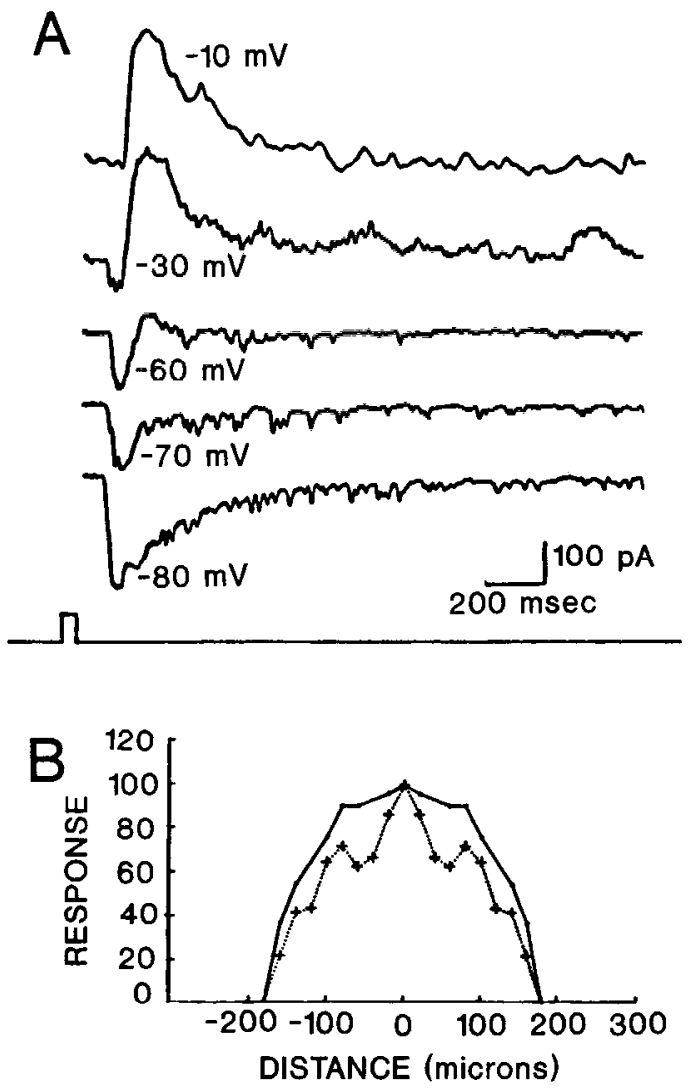

Figure 7. Wide field amacrine cell currents. $A$, Reversal potentials of separate inward and outward synaptic currents of wide field transient amacrine cell. Two components are evident, an early, transient (inward) current that reverses near $0 \mathrm{mV}$ and a later, slow (outward) current that reverses near $-65 \mathrm{mV}$. Note that near $-65 \mathrm{mV}$, the reversal potential for the late, slow component, the inward current remained transient, suggesting that this synaptic input is itself transient. The outward current becomes inward more negative than $-65 \mathrm{mV}$, thereby extending the apparent current at $-80 \mathrm{mV}$. B. Spatial profile for the antagonistic components measured as described in Figure $6 B$. The response profiles were measured only from the location of peak response to one side of the profile, and the curve was then rotated around the origin. The profile for both the inward and outward antagonistic components spanned about $200 \mu \mathrm{m}$. More than 45 wide field cells were studied.

\section{Narrow field amacrine cells have single, sustained excitatory input and narrow spatial sensitivity profile}

Figure $6 \mathrm{~A}$ shows a series of responses at different holding potentials in a narrow field oFF amacrine cell elicited by kainate puffs at the OPL. The responses reversed near $0 \mathrm{mV}$; currents appear to be similar in form at all potentials, suggesting that the synaptic input eliciting this current is composed primarily of a single, sustained excitatory component.

Figure $6 B$ shows the response in a narrow field ofF amacrine cell to puffs displaced laterally along its processes in $10 \mu \mathrm{m}$ increments. The response field for the narrow field cell spans about $200 \mu \mathrm{m}$. At the more lateral displacements, the response kinetics were slower, similar to the change in kinetics of the bipolar cell or slit-photocell calibration (see Materials and Methods). This suggests that $200 \mu \mathrm{m}$ may be an overestimate for the retinal region of sensitivity to the puff because the slow responses at lateral displacements may represent puff diffusion. 


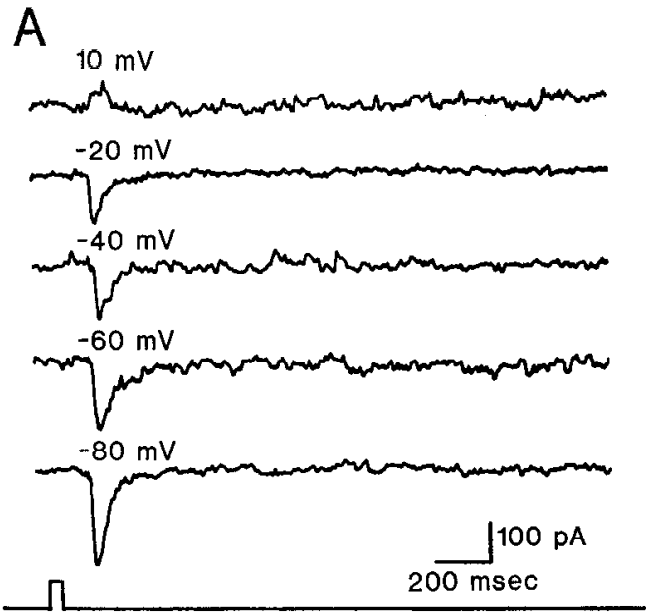

B

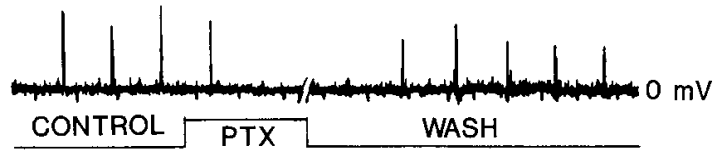

Figure 8. Picrotoxin block of late sustained current component in a wide field, transient amacrine cell. $A$, In the presence of picrotoxin, the late, slow outward current component of the response clearly seen in Figure $7 A$ was blocked. The inward current remained transient and still reversed near $0 \mathrm{mV}$. More than 30 cells were studied in this way. $B$, The membrane potential is held at $0 \mathrm{mV}$, which is the reversal potential for the fast, inward current and therefore isolates the slow, outward synaptic current. Kainate is puffed into the OPL cvery $5 \mathrm{sec}$ which elicits an outward current every $5 \mathrm{sec}$. This is done for several minutes until a reasonable approximation to a steady state is achieved. Control puff responses were then recorded for a period of about $20-25 \mathrm{sec}$ at which time picrotoxin $(50 \mu \mathrm{M})$ was added to the bath which eliminates the outward current. Washing (with control Ringer's solution) brought the outward current back to near control levels, but only after washing for several minutes (break in trace reflects about $2 \mathrm{~min}$ ).

\section{Wide field amacrine cells have transient, biphasic input currents and narrow sensitivity profiles}

Figure $7 \mathrm{~A}$ shows a series of responses elicited by kainate puffs at the OPL as measured in a wide field amacrine cell at different holding potentials. The response consists of at least 2 current components with different reversal potentials and kinetics. The initial brief inward transient current nulled near $0 \mathrm{mV}$. This current was followed by a slower, delayed, more sustained current that reversed near $-65 \mathrm{mV}$. Near $-65 \mathrm{mV}$, the reversal potential for the late, slow component, the inward current remained transient suggesting that this synaptic input is itself transient. These 2 components can be pharmacologically separated by $\mathrm{GABA}_{A}$ and $\mathrm{GABA}_{\mathrm{B}}$ receptor ligands, as shown below.

Figure $7 B$ shows the spatial profiles for both the inward and outward currents measured in the broad field amacrine cell. The inward current sensitivity profile was measured by holding the membrane at $-65 \mathrm{mV}$, near the reversal potential for the outward component, and moving the pipette laterally in $10-\mu \mathrm{m}$ increments along the OPL. The outward current sensitivity was measured in a similar way by holding the membrane at -10 $\mathrm{mV}$, near the reversal potential for the inward component. Both current sensitivity profiles spanned about $300 \mu \mathrm{m}$, far less than the full spread of the processes for the broad field cell, which
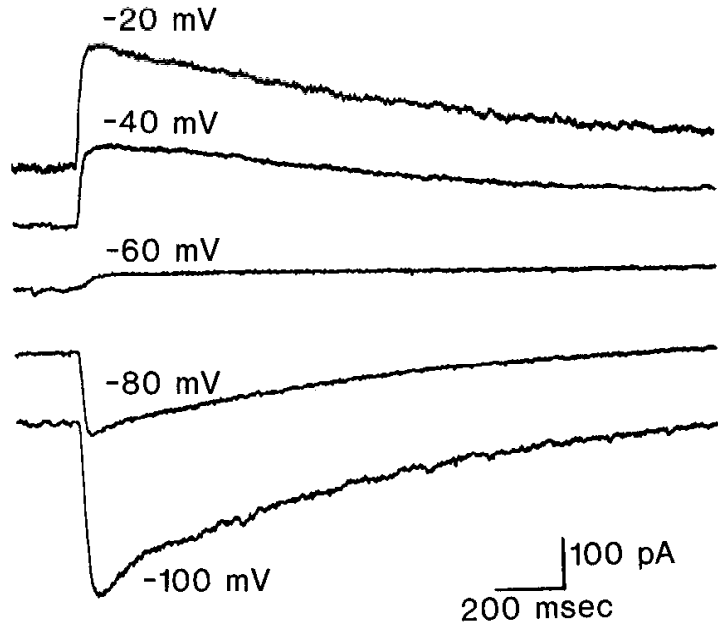

$几$

Figure 9. Direct effect of GABA on transient amacrine cell response. GABA was puffed at the IPL directly at the processes of a wide field amacrine cell. GABA elicited a sustained outward current that reversed near $-60 \mathrm{mV}$, the equilibrium potential for chloride, much like the response component blocked by picrotoxin in Figure 7. GABA acts directly at the amacrine cell membrane; a similar response was measured in the presence of cobalt in the bath, suggesting that GABA is acting directly at the wide field amacrine cell. Twelve cells were studied.

was typically greater than $500 \mu \mathrm{m}$. This suggests that the pharmacological sensitivity of the wide field amacrine cell is confined to a central region of its processes near the soma.

\section{Transient response is formed by pre- and postsynaptic GABAergic truncation of a sustained signal}

Figure 8 shows that the late outward current is due to a direct GABAergic input. Picrotoxin completely abolished the late outward current as shown in the series of responses in Figure $8 \mathrm{~A}$. The remaining inward current was transient and of common waveform at all potentials, reversing near $0 \mathrm{mV}$. Strychnine had no effect on either component.

The time course for the blocking action of picrotoxin on the outward current is shown in Figure $8 B$. The synaptically elicited outward current was isolated by holding the cell at $0 \mathrm{mV}$, the reversal potential for the initial inward current. A series of outward currents was elicited at $5 \mathrm{sec}$ intervals by puffs of kainate in the OPL. When picrotoxin $(50 \mu \mathrm{M})$ was added to the bath, the outward current was eliminated after about $5 \mathrm{sec}$. The response returned within 2 min after a wash of the picrotoxin.

Direct application of GABA (in the presence of $3 \mathrm{~mm}$ cobalt to block synaptic transmission) to the proccsses of the transicnt amacrine cell also elicited a current that reversed near $-60 \mathrm{mV}$ as shown in Figure 9. The reversal potential for the direct GABA application and the picrotoxin-blocked responses to OPL kainate puffs was within $10 \mathrm{mV}$ of $-62 \mathrm{mV}$, the calculated chloride Nernst potential. This suggests that the slow outward current is mediated by a GABA input impinging directly on the processes of the transient amacrine cell, thus increasing chloride conductance.

The transient inward current is formed by a presynaptic GABAergic signal

The inward current was dramatically altered by baclofen, a $\mathrm{GABA}_{\mathrm{B}}$ agonist (Robertson and Taylor, 1986), and AVA, a 
A
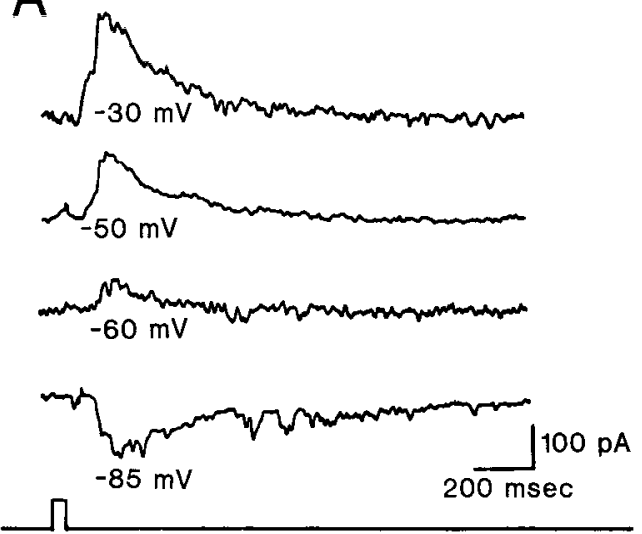

B

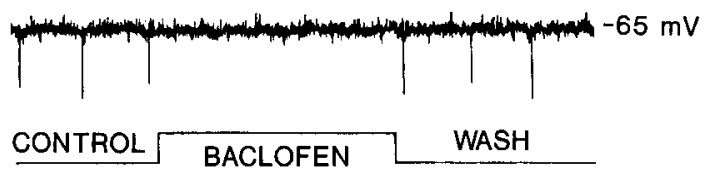

Figure 10. Effect of baclofen on the transient amacrine cell response $A$, In the presence of $50 \mu \mathrm{M}$ baclofen, the transient inward excitatory component of the response was reduced in amplitude, whereas the inhibitory component remained relatively unaffected. Twenty-three cells were studied. $B$, The membrane potential is held at $-65 \mathrm{mV}$ and kainate is puffed into the OPL every $5 \mathrm{sec}$ to elicit the fast, inward current. The outward current is eliminated here by holding the membrane near -65 $\mathrm{mV}$. Once the inward current reaches a steady state a series of control responses are recorded. Baclofen is then bath-applied, eliminating the inward current. Washing the retina with control Ringer's solution brings the response back to near control levels immediately, i.e., within $5 \mathrm{sec}$.

GABA $_{\mathrm{B}}$ antagonist (Muhyaddin et al., 1982; Nakahiro et al., 1985; Ong and Kerr, 1987). Figure $10 A$ shows that in the presence of $50 \mu \mathrm{M}$ baclofen the excitatory component of the response was blocked but the outward current was unaffected, still reversing near $-65 \mathrm{mV}$. In some cells the blockade of the inward current by baclofen was incomplete. In those cells, higher concentrations of baclofen did not increase the effect, although more time was required for recovery of response after the baclofen was removed from the bath. In the presence of baclofen the amacrine cell responded to direct puffs of kainate, suggesting that baclofen is acting at a site presynaptic to the amacrine cell membrane.

The time course for the effects of baclofen is shown in Figure $10 B$. The outward current was eliminated by holding the cell at $-65 \mathrm{mV}$, and a series of isolated inward currents was elicited every 5 sec by puffs of kainate into the OPL. When baclofen was then applied to the bath, the inward current was eliminated within $5 \mathrm{sec}$. A wash brought the response back to control levels within less than $5 \mathrm{sec}$.

When AVA was added to the bath (in addition to picrotoxin), the normally transient inward current became sustained at all potential levels, reversing at $-10 \mathrm{mV}$ as shown in Figure 11 . A similar sustained response was obtained when baclofen was added in the presence of AVA, suggesting that AVA, a GABA antagonist, blocked the action of baclofen, a $\mathrm{GABA}_{\mathrm{B}}$ agonist. These results suggest that the normally sustained bipolar response is truncated by an antagonistic interaction acting at a site presynaptic to the amacrine cell at $\mathrm{GABA}_{\mathrm{B}}$ receptor.
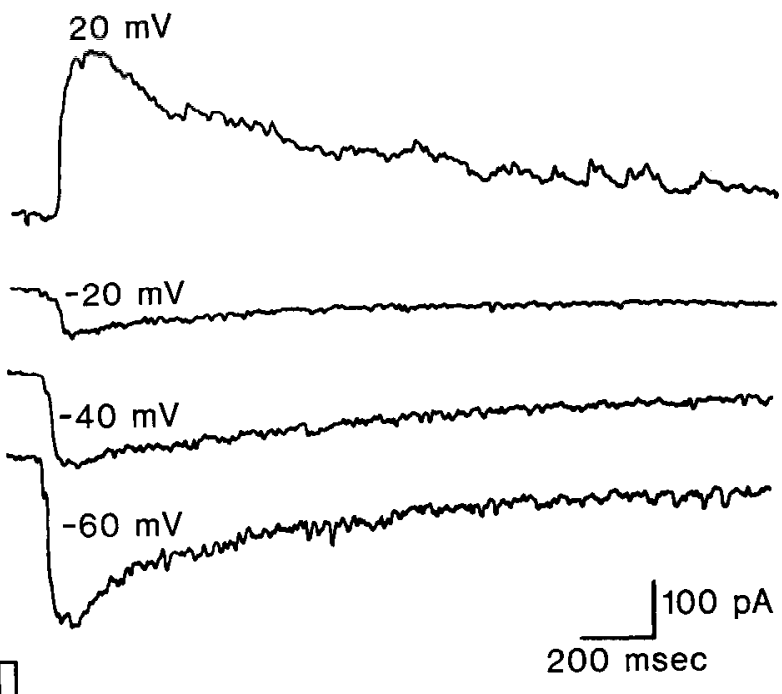

Figure 11. Effect of AVA on transient amacrine cell response. In the presence of AVA (in addition to picrotoxin; AVA is itself a GABA agonist), the previously transient inward current (Fig. $7 A$ ) became sustained with a similar waveform at all potential levels reversing near 0 $\mathrm{mV}$. The time course of this response resembled that of the bipolar cell (see Fig. $2 B$ ). Twenty cells were studied.

\section{Discussion}

Summary of the pharmacological interactions mediating transient response in the wide field amacrine cell

The pharmacological separation of the transient response components in the wide field amacrine cell by picrotoxin, baclofen, and AVA suggest a generalized scheme for the neural circuitry underlying GABAergic interactions. The components of response are summarized in Figure 12, $A-F$, and the scheme is presented in Figure 13.

The normal synaptic currents measured in a wide field amacrine cell are shown in Figure 12A. Picrotoxin, a GABA ${ }_{\mathrm{A}}$ antagonist, blocks the late slow outward current, as shown in Figure $12 B$. GABA puffed directly at the processes elicit an outward current with reversal potential near $-60 \mathrm{mV}$, similar to that of the picrotoxin-blocked current shown in Figure 9. These findings suggest that a GABAergic signal with slow time course normally impinges directly on the wide field amacrine cell to generate the slow outward current.

In the presence of picrotoxin, the remaining inward current was transient as shown in Figure 12B. The transient current is eliminated by baclofen, a $\mathrm{GABA}_{\mathrm{B}}$ agonist. Baclofen does not affect GABAergic inputs to the wide field amacrine cell directly. Baclofen is known to act at presynaptic sites (Ault and Nadler, 1981; Bowery et al., 1981; Giotti et al., 1983), where it can reduce release of transmitter (Johnston et al., 1980) or reduce calcium currents (Robertson and Taylor, 1986; Maguire et al., 1988). These findings suggest that baclofen decreases the excitatory input at a site presynaptic to the wide field amacrine cell.

In a complementary way, AVA extends the normally brief time course of the inward current shown in Figure $12 B$, so that it resembles the current in Figure $12 D$. AVA, a GABA ${ }_{\mathrm{B}}$ antagonist (Muhyaddin et al., 1982) is probably blocking the effect of an endogenous GABAergic signal that normally acts to truncate the response shown in Figure $12 D$, resulting in the response shown in Figure 12B. The difference between these 2 signals is an estimate of the time course of the truncating signal; it is 

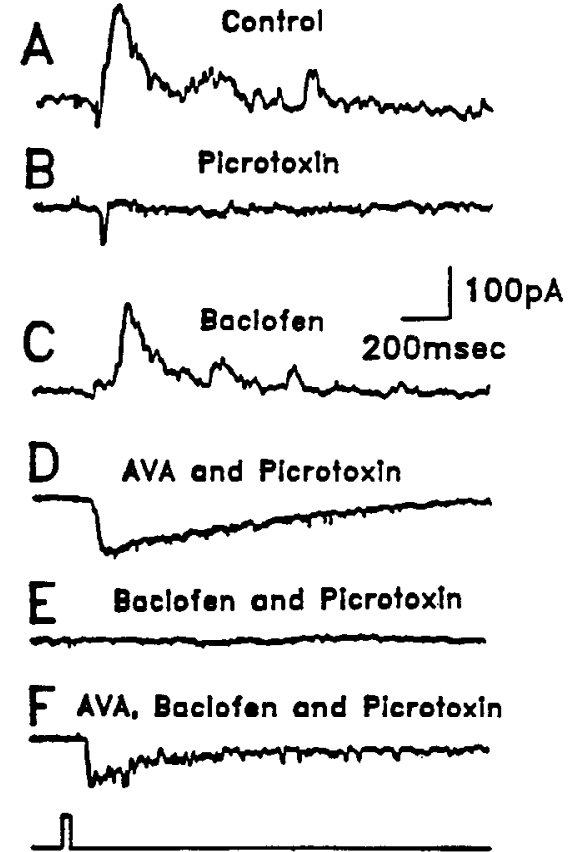

Figure 12. Summary of the pharmacological dissection of the synaptic input to the wide field, transient amacrine cell. All measurements were made in the same wide field amacrine cell at a holding potential of -30 $\mathrm{mV}$. $A$, Normal response consists of an initial transient inward current followed by a longer lasting outward current. $B$, The outward current was blocked by picrotoxin $(50 \mu \mathrm{M})$, but the initial inward current remained transient. $C$, Baclofen $(50 \mu \mathrm{M})$ completely blocked the transient inward current, but the slow outward component remained intact, suggesting that the transient excitatory current (but not the sustained outward current) is affected at GABA $A_{B}$ receptors. $D$, In AVA the normally transient inward current became sustained. Picrotoxin was also included bccausc AVA acts as a $\mathrm{GABA}_{\mathrm{A}}$ agonist. $E$, Baclofen and picrotoxin together completely eliminated all synaptic currents, suggesting that there are no other significant synaptic inputs. $F$, AVA $(0.5 \mathrm{~mm})$ blocked the suppressive effects of baclofen $(50 \mu \mathrm{M})$, demonstrating specificity of these pharmacological agents at a $\mathrm{GABA}_{\mathrm{B}}$ receptor.

sustained and slightly delayed with respect to the onset of the transient in Figure 12B.

In combination, baclofen and picrotoxin eliminate both the postsynaptic inhibition and the excitatory input as shown in Figure $12 E$. Finally, AVA blocks the action of baclofen, resulting in an extended inward current as shown in Figure $12 F$.

\section{A general scheme for GABAergic interactions mediating transient activity in wide field amacrine cells}

The results summarized in Figure 12 are represented schematically in Figure 13. Trace $A$ represents the excitatory signal; it is inferred from the response in Figure $12 F$ which represents the excitatory input with pre- and postsynaptic inhibition removed by picrotoxin and baclofen. Trace $B$ represents the signal originating at the GABA source and impinging on the $\mathrm{GABA}_{\mathrm{B}}$ receptors at the terminal; it is inferred from the waveform of the postsynaptic GABAergic input as shown in Figure $12 \mathrm{C}$ and the presynaptic GABAergic waveform given by the difference between Figure 12, $B$ and $F$.

Signal B must be delayed by about $200 \mathrm{msec}$ with respect to signal $A$ so that $B$ acts to reduce transmission only after the initial transient. The resulting transient signal $\mathrm{C}$ results from the antagonistic interaction of $B$ on $A$.

We have not measured a difference in latency between signals

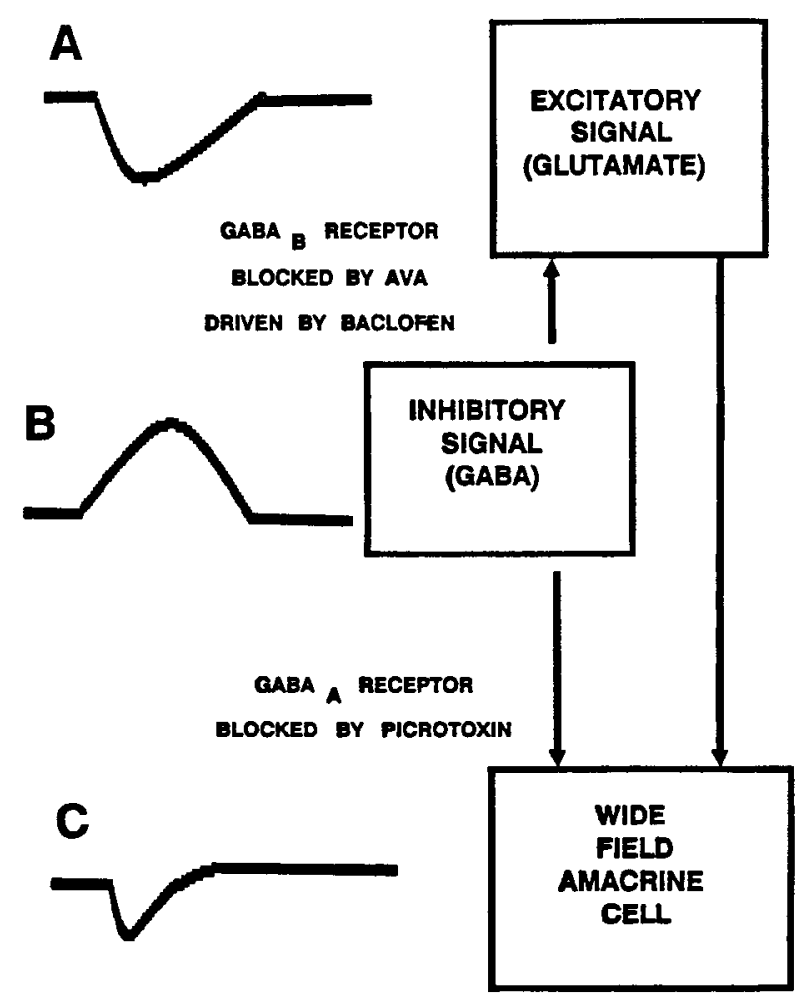

Figure 13. General scheme derived from the data in Figure 12. Wide field amacrine cell receives two inputs: (1) direct excitation, and (2) direct inhibition via $\mathrm{GABA}_{\mathrm{A}}$ receptors. A sustained excitatory signal $(A)$ is truncated by a sustained, slightly delayed GABA signal $(B)$ to generate a transient input $(C)$ to the wide field amacrine cell. The signals $A, B$, and $C$ are drawn from current components derived in Figure 12.

A and B, but the delay may involve the intracellular pathway from $\mathrm{GABA}_{\mathrm{B}}$ receptor to synaptic release site. For example, $\mathrm{GABA}_{\mathrm{B}}$ receptors are known to act through a G-protein (Dolphin and Scott, 1987); and possibly protein kinase C (Rane and Dunlap, 1986). Recent evidence suggests that neurotransmitter receptor-activated $\mathrm{G}$-proteins can directly modulate channels (Scolt and Dolphin, 1987) and can operate in as little as $50 \mathrm{msec}$ (Pfaffinger et al., 1985).

\section{The bipolar terminal may be the source of the excitatory signal}

We infer that the neural elements corresponding to the sources of excitation in Figure 13 are bipolar terminals. Earlier studies have shown that bipolar terminals release a glutamate-like excitatory transmitter (Slaughter and Miller, 1983a, b). There are numerous bipolar-to-amacrine synapses (Dowling and Wcrblin, 1969; Wong-Riley, 1974). Also, bipolar terminals receive a GABAergic input (Marc et al., 1978; Vaughn et al., 1981; Wu et al., 1981; Maple and Werblin, 1986). Thus, bipolar cell terminals appear to release the appropriate excitatory transmitter, receive the appropriate GABAergic input, and be in appropriate synaptic relation to amacrine cells.

\section{Separate sustained and transient bipolar terminals}

If the element labeled "excitation" in Figure 13 is in fact a bipolar terminal, then the $\mathrm{GABA}_{B}$ input dictates that its release is normally transient. But release from another separate population of bipolar terminals must be sustained, because there exist sustained amacrine and ganglion cells. The assumptions leading 


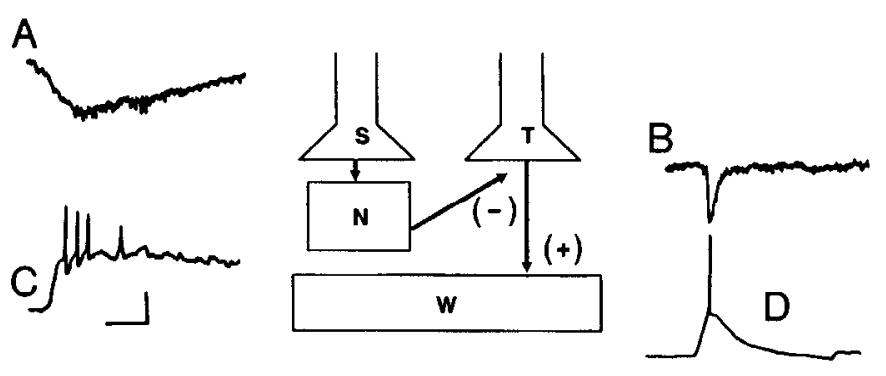

Figure 14. Scheme for interactions mediating change detection. Vertical arrows represent glutamate pathways; diagonal arrow indicates a GABA pathway. Identified elements are intended to represent populations of cells. The slow narrow field amacrine cell $(N)$ receives excitatory input $(A)$ from a slow bipolar cell terminal $(S)$. The output of this cell (C) in turn feeds back to a separate class of transient bipolar terminals $(T)$, truncating release from this terminal via a $\mathrm{GABA}_{\mathrm{B}}$ receptor. (The slow amacrine cell also inhibits the fast wide field amacrine cell $(W)$ directly via a $\mathrm{GABA}_{\mathrm{A}}$ receptor.) The traces represent inferred signals in this pathway. $A$. Inferred output of the sustained bipolar terminal recorded as the excitatory synaptic current in the narrow field amacrine cell. $B$, Inferred output of the transient or fast bipolar terminal recorded as the excitatory current in the wide field amacrine cell. $C$, Output of the narrow field amacrine cell recorded under current clamp. This is a steadily spiking signal. $D$, Output of the wide field amacrine cell recorded under current clamp, showing single-spike activity (Barnes and Werblin, 1986). Calibration: $100 \mathrm{pA}, 200 \mathrm{msec}$ for traces $A$ and $B ; 20 \mathrm{mV}, 200$ msec for traces $C$ and $D$.

to the scheme in Figure 13, then, predict the existence of at least 2 separate populations of bipolar terminals, one sustained, the other transient. No sustained-transient distinction has been made recording from bipolar cell bodies, so if this dichotomy exists, it must be initiated proximal to the bipolar soma, probably at the terminal itself.

\section{Narrow field amacrine cell may be the GABAergic source}

Earlier studies suggest that the narrow field amacrine cell may be the source of GABAergic input to the bipolar terminals. Narrow ficld amacrinc cells have bcen implicated as GABAcrgic in fish (Marc et al., 1978) and in salamander (Watt et al., 1987; Werblin et al., 1988). The response of the narrow field amacrine cells and that of both the pre- and postsynaptic GABAergic inputs in Figure $13 B$ are sustained. Finally, the spatial profile of the GABAergic input and that of the sensitivity of the narrow field amacrine cell span only about $200 \mu \mathrm{m}$. Thus, the pharmacological, temporal, and spatial properties of the narrow field amacrine cell match those of the input to the bipolar terminals.

\section{Neuronal circuit for a change-detection subunit}

The general pharmacological scheme shown in Figure 13 can be made more specific by incorporating the (sustained and transient) bipolar cell synaptic terminals as the source of excitation, and the narrow field amacrine cell as the source of GABAergic pre- and postsynaptic inputs. The circuity is shown in Figure 14. These 4 cell types and thcir synaptic interactions form a change detecting subunit.

In this scheme, a population of sustained bipolar terminals $(\mathrm{S})$ drives the narrow field amacrine cell $(\mathrm{N})$ with a sustained input (A). The narrow field amacrine cell responds with a sustained train of spikes $(C)$, driving the sustained release of GABA to truncate the response at the transient bipolar terminal (T). As a result of the truncating feedback, a transient signal (B) is generated at these terminals that drives the wide field amacrine cell (W). These cells typically spike only once (D) in response to each excitatory input (Barnes and Werblin, 1986; Eliasof et al., 1987).

\section{Separate subunits for on and ofF transients}

The kainate puffs used in these studies selectively drive a subunit consisting of the ofF bipolar and amacrine cells and therefore generate the off transient synaptic current in the wide field amacrine cell. But light generates transient responses at both oN and oFF. This suggests that there is a separate, complementary subunit consisting of sustained and transient on bipolars, coupled with a sustained on amacrine cell, that generates an oN transient synaptic current in the wide field amacrine cell. Therefore, the complete subunit, responding to the arrival or departure of either a light or dark object, would be composed of the 7 cell types, including oN and oFF, transient and sustained bipolar cells, ON and OFF sustained amacrine cells, and an ON-OFF transient amacrine cell.

\section{References}

Attwell, D., P. Mobbs, M. Tessier-Lavigne, and M. Wilson (1987) Neurotransmitter-induced currents in retinal bipolar cells of the axolotl, Ambystoma mexicanum. J. Physiol. (Lond.) 387: 125-161.

Ault, B., and J. V. Nadler (1981) Baclofen selectively inhibits transmission at synapses made by axons of CA3 pyramidal cells in the hippocampal slice. J. Pharmac. Exp. Ther. 223: 291-297.

Barlow, H. B., and W. R. Levick (1965) The mechanisms of directionally selective units in rabbit's retina. J. Physiol. (Lond.) 178:477504.

Barnes, S., and F. S. Werblin (1986) Gated currents generate single spike activity in amacrine cells of the tiger salamander retina. Proc. Natl. Acad. Sci. USA 83: 1509-1512.

Barnes, S., and F. S. Werblin (1987) Direct excitatory and lateral inhibitory synaptic inputs to amacrine cells in the tiger salamander retina. Brain Res. 406: 233-237.

Belgum, J. H., D. R. Dvorak, and J. S. McReynolds (1983) Sustained and transient synaptic inputs to ganglion cells in the mudpuppy retina. J. Physiol. (Lond.) 340: 599-610.

Belgum, J. H., D. R. Dvorak, and J. S. McReynolds (1984) Strychnine blocks transient but not sustained inhibition in mudpuppy retinal ganglion cells. J. Physiol. (Lond.) 354: 273-286.

Bowery, N. G., A. Doble, D. R. Hill, A. L. Hudson, J. S. Shaw, M. G. Turnbull, and R. Warrington (1981) Biccuculline insensitive GABA receptors on peripheral autonomic nerve terminals. Eur. J. Pharmacol. 71: 53-70.

Brown, T. H., and D. Johnston (1983) Voltage-clamp analysis of mossy fiber synaptic input to hippocampal neurons. J. Neurophysiol. 50: 487-507.

Dolphin, A. C., and R. H. Scott (1987) Calcium channel currents and their inhibition by $(-)$ Baclofen in rat sensory neurons: Modulation by guanine nucleotides. J. Physiol. (Lond.) 386: 1-17.

Dowling, J. E., and F. S. Werblin (1969) Organization of retina of the mudpuppy, Necturus maculosus. I. Synaptic structure. J. Neurophysiol. 32: 315-338.

Eliasof, S., S. Barnes, and F. S. Werblin (1987) Amacrine cells make single spikes. J. Neurosci. 7: 3512-3524.

Famiglietti, E. V., Jr., and H. Kolb (1976) Structural basis of "ON"and "OFF"-center responses in retinal ganglion cells. Science 194 : 193-195.

Famiglietti, E. V., Jr., A. Kaneko, and M. Tachibana (1977) Neuronal architecture of ON and OFF pathways to ganglion cells in carp retina. Science 198: 1267-1269.

Frumkes, T. E., R. F. Miller, M. Slaughter, and R. F. Dacheux (1981) Physiological and pharmacological basis of GABA and glycine action on neurons of mudpuppy retina. III. Amacrine mediated inhibitory influences on ganglion cell receptive-field organization: A model. J. Neurophysiol, 45: 783-804.

Giotti, A., S. Luzzi, S. Spangnesi, and L. Zilletti (1983) GABA and $\mathrm{GABA}_{B}$ receptors mediate effects in guinea pig ileum. Br. J. Pharmacol. 78: 469-478. 
Hamill, O. P., A. Marty, E. Neher, B. Sakmann, and F. J. Sigworth (1981) Improved patch-clamp techniques for high resolution current recording from cells and cell-free membrane patches. Pfluegers Arch. 391: 85-100.

Johnston, G. A. R., M. H. Hailstone, and C. G. Freeman (1980) Baclofen: Stereoselective inhibition of excitant amino acid release. $J$. Pharm. Pharmacol. 32: 230-231.

Kaneko, A. (1970) Physiological and morphological identification of horizontal, bipolar, and amacrine cells in goldfish retina. J. Physiol. (Lond.) 207: 623-633.

Kaneko, A. (1973) Receptive field organization of bipolar and amacrine cells in the goldfish retina. J. Physiol. (Lond.) 235: 133-153.

Kolb, H. (1979) The inner plexiform layer in the retina of the cat: Electron microscopic observations. J. Neurocytol. 8: 295-329.

Lukasiewicz, P. D., and F. S. Werblin (1986) Three different forms of ganglion cell activity mediated by synaptic and voltage-gated currents. ARVO Abstr. 27: 130.

Maguire, G., B. Maple, P. Lukasiewicz, and F. Werblin (1988) Calcium channel currents of bipolar cell axon terminals are modulated via GABA $_{\mathrm{B}}$ receptors. Soc. Neurosci. Abstr. 14: 161

Maple, B. R., and F. S. Werblin (1986) Inhibitory feedback to bipolar cells in the tiger salamander retina. Neuroscience Abstr. 12: 634 .

Marc, R. E., W. K. Stcll, D. Bok, and D. M. K. Lam (1978) GABAergic pathways in the goldfish retina. J. Comp. Neurol. 182: 221-245.

Marchiafava, P. L., and V. Torre (1978) The responses of amacrine cells to light and intracellularly applied currents. J. Physiol. (Lond.) 276: 83-102.

Miller, R. F. (1979) The neuronal basis of ganglion cell receptive field organization and the physiology of amacrine cells. In The Neurosciences: Fourth Study Program, F. O. Schmitt and F. G. Worden, eds., pp. 227-245, MIT Press, Cambridge, MA.

Miller, R. F., and R. F. Dacheux (1976) Synaptic organization and ionic basis of $\mathrm{ON}$ and OFF channels in mudpuppy: I. Intracellular analysis of chloride sensitive electrogenic properties of receptors, horizontal cells, bipolar cells, and amacrine cells. J. Gen. Physiol. 67: 639-659.

Miller, R. F., T. E. Frumkes, S. Slaughter, and R. F. Dacheux (1981) Physiological and pharmacological basis of GABA and glycine action on neurons of mudpuppy retina. II. Amacrine and ganglion cells. J. Neurophysiol. 45: 764-782.

Mittman, S., and D. R. Copenhagen (1985) Glycine mimics transient inhibitory synaptic input to whole-cell patch clamped retinal ganglion cells. Invest. Ophthalmol. Vis. Sci. (Supp.) 26: 312.

Muhyaddin, M., P. J. Roberts, and G. N. Woodruff (1982) Presynaptic g-aminobutyric acid receptors in the rat anococcygeus muscle and their antagonism by 5-aminovaleric acid. Br. J. Pharmacol. 77: 163168.

Nakahiro, M., S. Kihachi, I. Yamoda, and H. Yoshida (1985) Antagonistic effect of g-amino valeric acid on bicuculline-insensitive $\mathrm{g}$ aminobutyric acid $\left(\mathrm{GABA}_{\mathrm{B}}\right)$ sites in rat's brain. Neurosci. Lett. 57: 263-266.

Nelson, R., E. V. Famiglietti, and H. Kolb (1978) Intracellular staining reveals different levels of stratification for ON and OFF center ganglion cells in cat retina. J. Neurophysiol. 41: 472-483.

Ong, J., and D. I. B. Kerr (1987) Comparison of GABA-induced responses in various segments of the guinea-pig intestine. Eur. $J$. Pharmacol. 134: 349-353.

Pfaffinger, P. J., J. M. Martin, D. D. Hunter, N. M. Nathanson, and B. Hille (1985) GTP-binding proteins couple cardiac muscarinic receptors to K channel. Nature 317: 536-538.

Rane, S. G., and K. Dunlap (1986) Kinase C activator 1,2 oleoylacetylglycerol attenuates voltage-dependent calcium current in sensory neurons. Proc. Natl. Acad. Sci. USA 83: 184-188.

Robertson, B., and W. R. Taylor (1986) Effects of g-aminobutyric acid and ( )Baclofen on calcium and potassium currents in cat dorsal root ganglion neurones in vitro. Br. J. Pharmacol. 89: 661-672.

Scott, R. H., and A. C. Dolphin (1987) Activation of a G protein promotes agonist responses to calcium channel ligands. Nature 330 : 760-762.

Shiells, R. A., G. Falk, and S. Naghshineh (1981) Action of glutamate and aspartate analogues on rod horizontal and bipolar cells. Nature 294: 592-594.
Slaughter, M. M., and R. F. Miller (1983a) Bipolar cells in the mudpuppy retina use an excitatory amino acid neurotransmitter. Nature 303: 537-538.

Slaughter, M. M., and R. F. Miller (1983b) The role of excitatory amino acid transmitters in the mudpuppy retina: An analysis with kainic acid and n-methyl aspartate. J. Neurosci. 3: 1701-1711.

Slaughter, M. M., and R. F. Miller (1985) The role of glutamate in information processing in the distal retina. In Neurocircuitry of the Retina: $A$ Cajall Memorial, A. Gallego and P. Gouras, eds., Elsevier, New York.

Stell, W. K., A. T. Ishida, and D. O. Lightfoot (1977) Structural basis for $O N$ - and OFF-center responses in the retina of the goldfish. Science 198: 1269-1271.

Stewart, W. W. (1978) Functional connections between cells as revealed by a highly fluorescent naphthalimide tracer. Cell 14: 741759.

Tachibana, M., and A. Kaneko (1987) Bipolar cells receive negative feedback input from GABA-ergic amacrine cells. ARVO Abstr. 28; 51 .

Tessier-I avigne, M., D. Attwell, P. Mobhs, and M. Wilson (1988) Membrane currents in retinal bipolar cells of the axolotl. J. Gen. Physiol. 91: 49-72.

Toyoda, J., and M. Fujimoto (1984) Application of transretinal current stimulation for the study of bipolar-amacrine transmission. J. Gen. Physiol. 84: 915-925.

Toyoda, J. I., H. Hashimolo, and K. Ohtsu (1973) Bipolar-amacrine cell transmission in the carp retina. Vision Res. 13: 295-307.

Vallerga, S. (1981) Physiological and morphological identification of amacrine cells in the retina of the larval tiger salamander. Vision Res. 21: 1307-1317.

Vaughn, J. E., E. V. Famiglietti, R. P. Barber, K. Saito, E. Roberts, and C. E. Ribak (1981) GABAergic amacrine cells in rat retina, immunocytochemical identification and synaptic connectivity. J. Comp. Neurol. 197: 113-127.

Watt, C. B., T. Li, D. M. K. Lam, and S. M. Wu (1987) Autoradiographical localization of classical neurotransmitters in the larval tiger salamander retina. ARVO Abstr. 28: 349.

Werblin, F. S. (1970) Responses of retinal cells to moving spots: Intracellular recording in Necturus maculosis. J. Neurophysiol. 33: 342 350.

Werblin, F. S. (1972) Lateral interactions at inner plexiform layer of vertebrate retina: Antagonistic response to change. Science 175: 10081010.

Werblin, F. S. (1977) Regenerative amacrine cell depolarization and formation of ON-OFF ganglion cell response. J. Physiol. (Lond.) 264: 767-785.

Werblin, F. S. (1978) Transmission along and between rods in the retina of the tiger salamander. J. Physiol. (Lond.) 294: 613-626.

Werblin, F. S. (1979) Integrative pathways in local circuits between slow-potential cells in the retina. In The Neurosciences: Fourth Study Program, F. S. Schmitt and F. G. Worden, cds., pp. 193-211, MIT Press, Cambridge, MA.

Werblin, F. S., and D. R. Copenhagen (1974) Control of retinal sensitivity. III. Lateral interactions at the inner plexiform layer. J. Gen. Physiol. 63: 88-110.

Werblin, F. S., and J. E. Dowling (1969) Organization of the retina of the mudpuppy, II. Intracellular recording. J. Neurophysiol. 32 . $339-355$

Werblin, F. S., G. W. Maguire, P. D. Lukasiewicz, S. R. Eliasof, and S. $\mathrm{Wu}$ (1988) Neural interactions mediating the detection of motion in the retina of the tiger salamander. Visual Neurosci. 1: 317-329.

Wong-Riley, M. T. T. (1974) Synaptic organization of the inner plexiform layer in the retina of the tiger salamander. J. Neurocytol. 3: 133.

Wu, J. Y., C. Brandon, Y. T. Su, and D. M. K. Lam (1981) Immunocytochemical and autoradiographic localization of GABA system in the vertebrate retina. Mo. Cell Biochem. 39: 229-237.

Wunk, D. F., and F. S. Werblin (1978) Synaptic inputs to the ganglion cells in the tiger salamander retina. J. Gen. Physiol. 73: 265-286. 